\title{
Pelatihan Accurate Bagi Guru SMA/SMK Se-Kabupaten Banyuwangi
}

\author{
Anak Agung Gde Satia Utama ${ }^{{ }^{*}}$ dan Dian Pratama ${ }^{1}$ \\ ${ }^{1}$ Program Studi Akuntansi, Universitas Airlangga, Jl. Airlangga No. 4, Surabaya, Indonesia, 60286 \\ *Email Korespondensi: gde.agung@feb.unair.ac.id
}

\begin{abstract}
Abstrak
Software ACCURATE Versi 5 (V.5) merupakan salah satu Software atau aplikasi akuntansi, aplikasi ini dapat digunakan untuk berbagai jenis perusahaan baik jasa, dagang, maupun manufaktur. Penggunaan aplikasi ACCURATE ini, akan memudahkan pelaporan keuangan dan dapat disajikan secara real time. Perkembangan zaman dan teknologi, menuntut guru-guru akuntansi untuk memahami dan kemampuan menggunakan aplikasi ini agar bisa diajarkan kepada murid-muridnya. Melihat akan kurangnya kemampuan guru SMA/SMK khususnya mata pelajaran Akuntansi dalam mengoperasikan aplikasi komputer akuntansi, mendorong prodi Akuntansi PSDKU Universitas Airlangga untuk mengadakan pengabdian masyarakat dengan mengadakan pelatihan kepada guru SMA/SMK se-Kabupaten Banyuwangi dalam menggunakan aplikasi ACCURATE V. 5 untuk mempermudah pemahaman guru SMA/SMK se-Kabupaten Banyuwangi dalam mengoperasikan aplikasi ACCURATE V.5. Program pengabdian ini dilaksanakan selama sehari penuh. Dimulai dari pengenalan terhadap aplikasi ACCURATE V.5, perbedaan serta keunggulannya dibanding MYOB, praktik langsung penggunaan ACCURATE V.5, dan juga sharing discussion dengan pemateri untuk menambah pemahaman dan kemampuan peserta. Hasil program pengabdian masyarakat ini berupa pemahaman dan skill peserta pelatihan terkait pengoperasian ACCURATE V.5, sehingga memperlancar proses pembelajaran di sekolah masing - masing.
\end{abstract}

Kata kunci: Pengabdian masyarakat; pelatihan; accurate; guru

\begin{abstract}
ACCURATE Desktop Edition Version 5 (V.5) Software is an Accounting Software that can be used for Trading Companies, Service Companies, Contracting Companies or for Manufacturing Companies. By using the ACCURATE Desktop Software Version 5 you will get financial reports in real time. Along with the times and technology, the teachers are required to understand this application in order to be taught to their students. Seeing the lack of ability of high school / vocational high school teachers especially accounting subjects in operating accounting computer applications, encouraging PSDKU Accounting Study Program Airlangga University to provide community service by conducting training for high school / vocational teachers throughout Banyuwangi in using the ACCURATE V.5 application to facilitate their understanding . This service program is carried out for a full day. Starting with the introduction to the ACCURATE V.5 application, its differences and advantages compared to MYOB, the direct practice of using ACCURATE V.5, and also sharing discussions with speakers to increase participants' understanding and ability. The result of this dedication is that participants' understanding and skills will improve, so that it is hoped that it will expedite their learning process.
\end{abstract}

Keywords: Community service; training; ACCURATE Version 5; teacher

Format Sitasi: Utama, A, A, G, S., \& Pratama, D. (2020). Pelatihan Accurate Bagi Guru SMA/SMK SeKabupaten Banyuwangi. Jurnal Solma, 09(2), 316-322. Doi: http://dx.doi.org/10.22236/solma.v9i2.4892

Diterima: 10 April 2020 | Revisi: 2 September 2020 | Dipublikasikan: 30 Oktober 2020


(C) 2020 Oleh authors. Lisensi Jurnal Solma, LPPM-Uhamka, Jakarta. Artikel ini bersifat open access yang didistribusikan di bawah syarat dan ketentuan Creative Commons Attribution (CC BY) license. (http://creativecommons.org/licenses/by/4.0/).

\section{PENDAHULUAN}

Selama ini, pembelajaran komputer akuntansi yang ada di SMK menggunakan aplikasi MYOB yang merupakan akronim dari Mind your own business, yang merupakan produk Australia (Biduri et al., 2020). Aplikasi MYOB merupakan aplikasi pembukuan (akuntansi) yang ditujukan bagi usaha kecil (UMKM) yang dibangun secara terpadu (Rohmah et al., 2019). MYOB dikembangkan oleh MYOB Limited Australia, dan kini telah dikembangkan diberbagai negara termasuk Indonesia. Standar kelulusan dan ujian juga menggunakan MYOB, akan tetapi diera perkembangan teknologi ini, siswa dan guru tidak hanya dituntut memahami satu aplikasi saja, akan tetapi berbagai aplikasi akuntansi yang ada, salah satunya adalah ACCURATE Versi 5 (Siregar, 2018).

ACCURATE adalah aplikasi yang digunakan untuk memudahkan proses akuntansi (Helmayunita et al., 2019). Dengan aplikasi ACCURATE, maka proses akuntansi hanya sampai tahap penjurnalan saja, sedangkan proses selanjutnya dilakukan oleh sistem (Ramadhani \& Sribina, 2019). ACCURATE merupakan perangkat lunak yang dirancang di Indonesia, dan mulai dikenalkan sejak tahun 2000 (Husda et al., 2019). Aplikasi tersebut dirancang dengan mengikuti perkembangan PSAK yang menjadi standar akuntansi di Indonesia (Prima \& Yusran, 2018), dan telah berevolusi hingga menghasilkan ACCURATE V.5 (Anna, 2019). Selain itu, ACCURATE juga memiliki versi lain seperti ACCURATE Standard Edition, Deluxe Edition dan Enterprise Edition (Astuti, 2019). ACCURATE diperuntukkan untuk digunakan pada berbagai jenis usaha mulai dari jasa, dagang, pabrikasi, tambang, kontraktor, dan manufaktur (Kudhori \& Setia, 2019).

Kelebihan yang dimiliki oleh ACCURATE antara lain menggunakan database server firebird berbasis SQL (Finatariani et al., 2019) sehingga mampu melayani ratusan user (Rachmawati, 2016). Penggunaan ACCURATE menyebabkan efisiensi biaya, karena tidak memerlukan tambahan biaya perbaikan yang rutin. ACCURATE juga menyediakan layanan yang user friendly, dimana pengguna tidak perlu melakukan posting, dan transaksi bisa dicatat secara real time (Yuliana, 2013). ACCURATE juga tersedia dalam dua bahasa yakni Indonesia dan Inggris. Kemudahan lainnya adalah, laporan dapat dilihat secara langsung dengan aplikasi microsoft excel, faktur yang dapat di customize oleh user, serta kemudahan dalam urusan perpajakan, karena telah disesuaikan dengan aturan yang ada di Indonesia (Darmanto, 2017).

Berbagai keunggulan yang dimiliki ACCURATE tersebut, seharusnya direspon para guru SMA/SMK di Kabupaten Banyuwangi dengan mempelajarinya untuk tujuan pembelajaran. Berdasarkan survey yang dilakukan oleh pantia penyelenggara pengabdian masyarakat, justru sebagian besar dari para guru kurang memahami dan bahkan tidak pernah menggunakan aplikasi ACCURATE. Berdasarkan hasil survey tersebut, PSDKU Universitas Airlangga mengadakan program pengabdian kepada masyarakat, yang bertujuan untuk memberikan pengetahuan dan kemampuan dalam mengoperasikan aplikasi ACCURATE Versi 5. 


\section{MASALAH}

ACCURATE memiliki berbagai kelebihan dan keunggulan sebagaimana dijelaskan pada bagian pendahuluan, tidak banyak lembaga pendidikan baik SMA maupun SMK yang mengajarkan ACCURATE kepada siswanya. Permasalahan tersebut disebabkan karena minimnya pemahaman terhadap aplikasi ACCURATE yang dimiliki oleh para guru.

Berdasarkan hasil analisis permasalahan yang telah diuraikan, yakni kurangnya pemahaman para guru tentang pengoperasian aplikasi ACCURATE Versi 5, Program studi Akuntansi, PSDKU Universitas Airlangga berinisiatif untuk melaksanakan program pengabdian kepada masyarakat berupa pelatihan guru SMA/SMK se-Kabupaten Banyuwangi dalam mengoperasikan aplikasi ACCURATE Versi 5, guna menunjang proses pembelajaran di sekolah masing - masing.

\section{METODE PELAKSANAAN}

Metode yang digunakan dalam kegiatan pengabdian kepada masyarakat Pelatihan ACCURATE bagi guru SMA/SMK Se-Kabupaten Banyuwangi adalah sebagai berikut :

1. Pemberdayaan Masyarakat Sasaran

Sasaran dari program pengabdian yang ini adalah guru SMA yang tergabung dalam MGMP (Musyawarah Guru Mata Pelajaran) ekonomi dan guru SMK yang tergabung dalam MGMP Akuntansi se Kabupaten Banyuwangi.

2. Analisa Potensi dan Sosialisasi Program

Sebelum melaksanakan pengabdian masyarakat, terlebih dahulu kami melaksanakan analisis terhadap potensi sasaran kegiatan. Tahap ini dilaksanakan dengan pengadaan survey terkait ketertarikan sasaran dengan pelatihan accurate, serta antusiasme sasaran dalam mempelajari penggunaan aplikasi ACCURATE Versi 5.

3. Pemilihan Mitra

Dalam program pengabdian ini, mitra kerjanya adalah pemateri yang ahli dibidangnya (ACCURATE Versi 5), tenaga pendidik dalam menyiapkan sarana yang dibutuhkan, serta SMKN Ihya’ Ulumuddin Singojuruh sebagai penyedia tempat kegiatan.

4. Pembentukan Tim Kerja

Pembentukan tim kerja dilakukan sebelum sosialisasi pengenalan software ACCURATE Versi 5 yang dilakukan pada bulan Oktober 2019. Panitia terdiri dari 7 orang yang direkomendasikan oleh Ketua Himpunan Mahasiswa Akuntansi. Yang menjadi tim untuk mengurus apapun selama kegiatan ini berlangsung.

5. Pelatihan Peserta

Pelatihan dilakukan pada tanggal 30 November 2019, dengan agenda acara yang dimulai dengan menyanyikan lagu kebangsaan, kemudian sambutan-sambutan, dilanjut dengan pelatihan ACCURATE Versi 5 yang dilakukan secara interaktif dan ditutup dengan foto bersama. Dapat disimpulkan bahwa kegiatan ini mendapat respon positif dari para guru yang menjadi peserta pelatihan, dibuktikan dengan antusiasme kehadiran dari perwakilan masing - masing sekolah yang ada. Pada akhirnya kegiatan ini dapat diselesaikan dengan baik dengan menambahnya tingkat pengetahuan peserta. 


\section{HASIL DAN PEMBAHASAN}

Pelatihan ACCURATE Versi 5 yang diselenggarakan Prodi Akuntansi PSDKU Universitas Airlangga di Banyuwangi dilaksanakan selama sehari penuh, bekerjasama dengan mahasiswa, dosen, SMK Negeri Ihya' Ulumudin dan MGMP. Keberhasilan pelatihan ini dilalui dengan beberapa tahapan diantaranya:

\section{Pemberdayaan Guru SMA/SMK se-Banyuwangi}

Peserta yang dilibatkan dalam kegiatan ini adalah guru SMA mata pelajaran Ekonomi dan guru SMK mata pelajaran komputer Akuntansi. Pemberdayaan ini adalah bentuk dari pengamalan Tri Dharma Perguruan Tinggi yang terdiri dari pendidikan dan pengajaran dan juga pengabdian kepada masyarakat yang dikolaborasikan. Kolaborasinya ditunjukkan dengan program pemberdayaan yang mengedepankan pada peningkatan kualitas pendidikan dan pengajaran.

\section{Analisis potensi sasaran kegiatan dan sosialisasi program}

Analisis mengenai potensi sasaran dilaksanakan dengan survey terhadap antusiasme dan ketertarikan peserta kegiatan untuk mempelajari aplikasi ACCURATE Versi 5. Berdasarkan hasil kuisioner yang telah dibagikan kepada peserta, diketahui hasil bahwa pelayanan yang diberikan memuaskan para peserta kegiatan, yang ditunjukkan dalam diagram berikut :

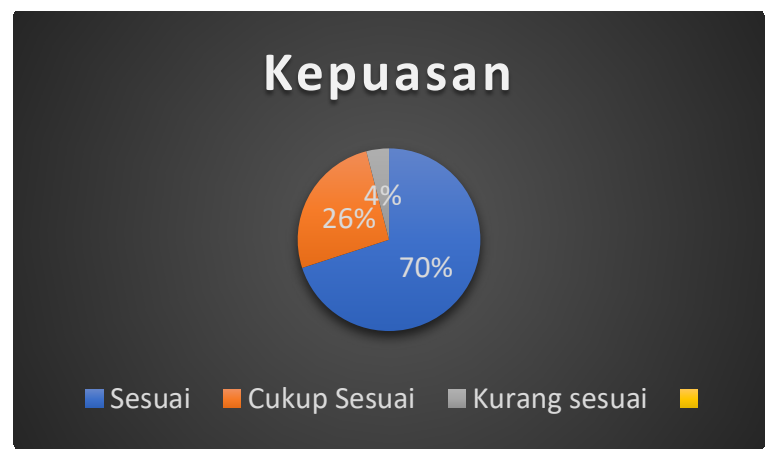

Gambar 1. Analisis potensi dan kepuasan peserta kegiatan

Sedangkan sosialisasi program dilakukan untuk memberikan persebaran yang merata bagi peserta sasaran yang tersebar di Kabupaten Banyuwangi, sehingga yang menjadi peserta bukan hanya beberapa perwakilan sekolah, melainkan semua sekolah yang ada. Dalam kegiatan ini peserta berasal dari berbagai SMK yang ada di Banyuwangi dan beberapa guru SMA Ekonomi.

\section{Pemilihan Mitra}

Mitra kerja dalam program pengabdian masyarakat ini adalah pemateri yang ahli dalam bidang pengoperasian aplikasi ACCURATE Versi 5, dan SMKN Ihya' Ulumudin Singojurih yang menyiapkan sarana dan prasarana, serta tempat pelaksanaan kegiatan. Dalam kegiatan ini pemateri diberikan oleh Ibu Eka Helmi Agustin S.A, CAP, dan Ria Rejekiwati, SE., CAAT.

\section{Pembentukan Tim Kerja}

Pembentukan tim kerja dilakukan sebelum sosialisasi pengenalan software ACCURATE Versi 5 yang dilakukan pada bulan Oktober 2019. Panitia terdiri dari 7 orang 
yang direkomendasikan oleh Ketua Himpunan Mahasiswa Akuntansi. Yang menjadi tim untuk mengurus apapun selama kegiatan ini berlangsung.

\section{Pelatihan Peserta}

Pelatihan dilakukan pada tanggal 30 November 2019, dengan susunan acara yang dimulai dengan menyanyikan lagu kebangsaan, kemudian sambutan-sambutan, dilanjut dengan pelatihan ACCURATE Versi 5, yang dilakukan secara interaktif dan ditutup dengan foto bersama. Permasalahan yang terjadi saat berlangsungnya acara adalah, para guru masih sangat asing dengan program ACCURATE Versi 5, sehingga dalam pelaksanaannya membutuhkan beberapa fasilitator yang mendampingi sekelompok peserta. Hal tersebut telah diantisipasi sebelumnya oleh panitia dengan menugaskan Mahasiswa Program Studi S1 Akuntansi untuk menjadi fasilitator yang mendampingi peserta selama acara berlangsung.

Hasil dari kegiatan ini adalah peningkatan pengetahuan dan juga skill para peserta dalam mengaplikasikan ACCURATE Versi 5, sebagai alat bantu dalam memperlancar proses pembelajaran di sekolah para peserta. Hasil pengabdian dapat dilihat dari perubahan yang terlihat pada hasil kuisioner saat pra acara dan juga pasca acara.

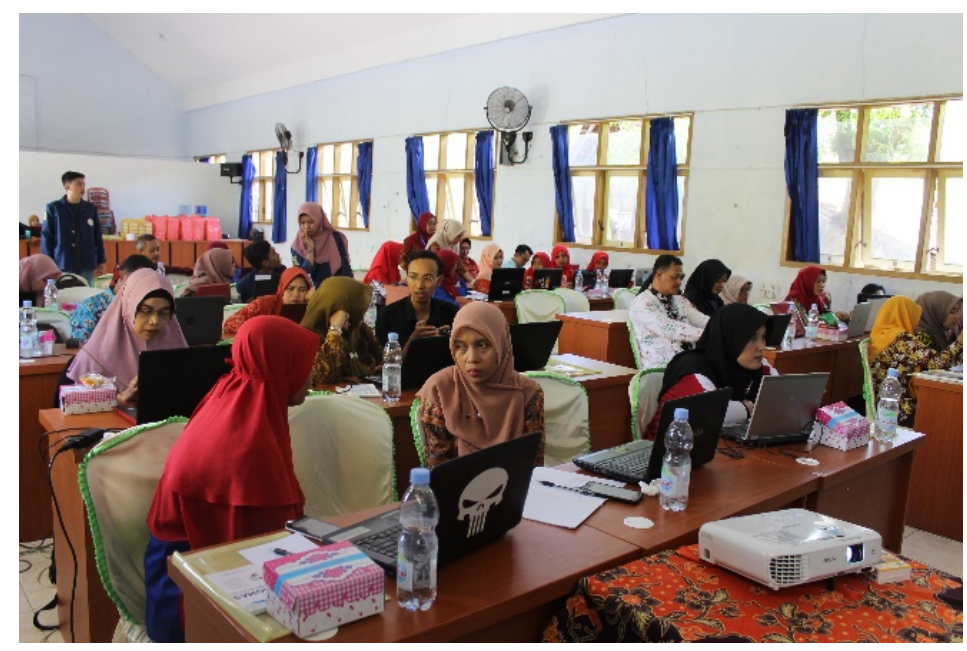

Gambar 2. Pelatihan Peserta dalam menggunakan ACCURATE Versi 5

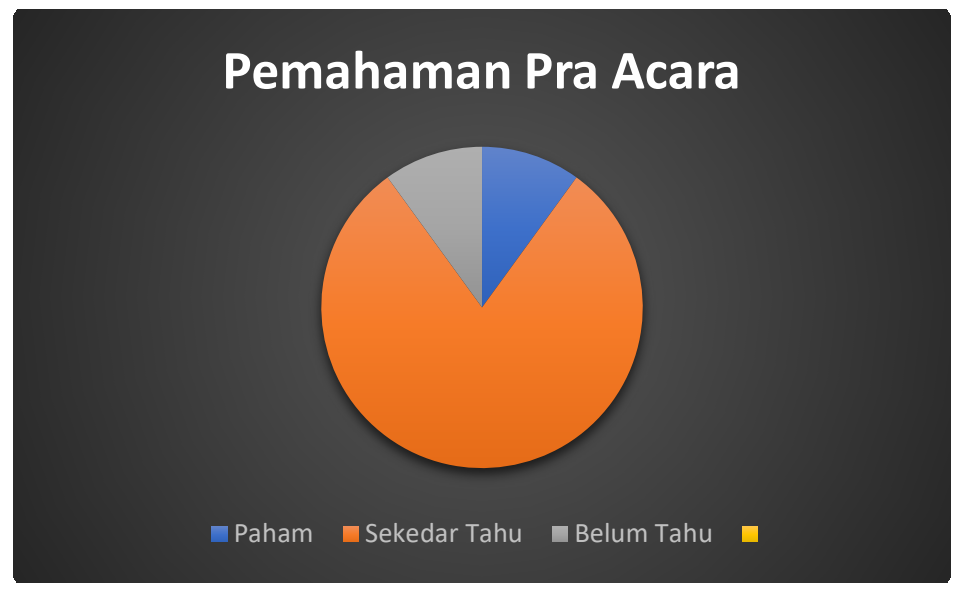

Gambar 3. Pemahaman peserta sebelum pelatihan penggunaan aplikasi NVIVO 12 Plus 


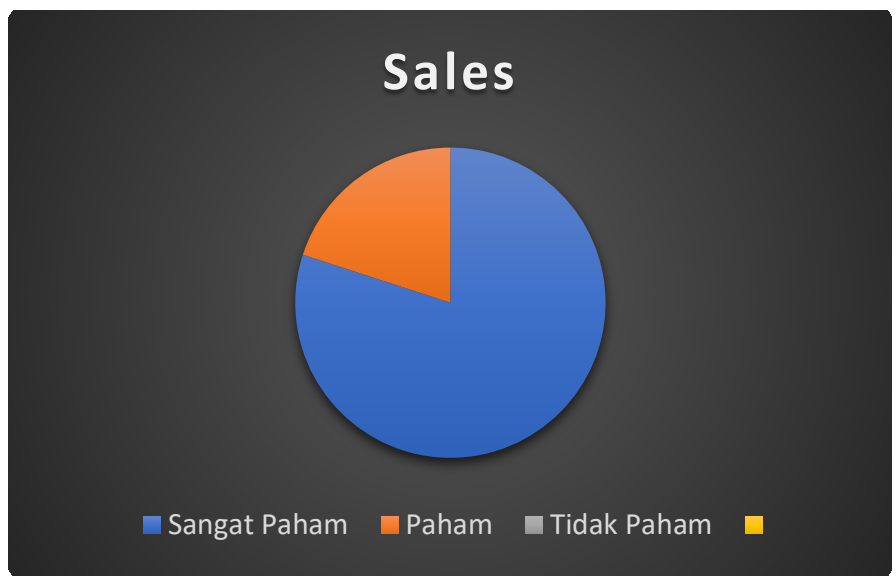

Gambar 4. Pemahaman peserta setelah pelatihan penggunaan aplikasi NVIVO 12 Plus

\section{KESIMPULAN}

Hasil dari program pengabdian masyarakat ini berupa peningkatan pemahaman dan skill peserta kegiatan yang dapat dilihat dari signifikansi perubahan dalam diagram hasil rekapitulasi kuisioner. Dapat disimpulkan bahwa kegiatan ini mendapat respon positif dari para guru yang menjadi peserta pelatihan, dibuktikan dengan antusiasme kehadiran dari perwakilan masing - masing sekolah yang ada. Pada akhirnya kegiatan ini dapat diselesaikan dengan baik dengan menambahnya tingkat pengetahuan peserta.

\section{UCAPAN TERIMA KASIH}

Terimakasih yang sebesar-besarnya kami ucapkan kepada Himpunan Mahasiswa Akuntansi, Panitia, SMKN Ihya' Ulumudin Singojuruh, Ibu Helmi dan bu Ria selaku pemateri dalam acara pelatihan ini.

\section{DAFTAR PUSTAKA}

Anna, Y. D. (2019). Penerapan Standar Akuntansi Keuangan Entitas Mikro Kecil Dan Menengah Pada Usaha Kecil Dan Menengah (Studi pada Pengusaha Keramik dan Craft Plered - Purwakarta). Dharma Bhakti Ekuitas, 03(02), 328-333.

Astuti, E. (2019). Pelatihan Myob Accounting Version 19 Pada Himpunan Mahasiswa Pendidikan Akuntansi. Jurnal Pengabdian Kepada Masyarakat, 16(1), 10-16. https://doi.org/10.21009/sarwahita.161.02

Biduri, S., Mulyadi, A., Choiriyah, I. U., \& Sidoarjo, U. M. (2020). Pendampingan implementasi sistem pencatatan akuntansi sekolah bagi dan smk nurul huda kepadangan kabupaten sidoarjo. Jurnal Terapan Abdimas, 5 No 1(Januari), 114-118.

Darmanto. (2017). Media Altenatif Software Praktikum Akuntansi SMK berbasis Open Source. In Seminar Nasional Ilmu Terapan (SNITER) 2017 - Universitas Widya Kartika, 1-6.

Finatariani, E., Darsita, I., Ekonomi, F., \& Pamulang, U. (2019). Peningkatan kemampuan bersaing di dunia kerja dengan pelatihan software zahir accounting. Abdimisi, 1(1), 6368.

Helmayunita, N., Serly, V., \& Honesty, H. N. (2019). PKM Peningkatan Kompetensi Guru 
SMK Dalam Bidang Komputer Akuntansi. Wahan Riset Akuntansi, 7(2), 1521-1528.

Husda, N. E., Putria, N. E., Domikoes, M. D. R., Rizqillah, M., Batam, U. P., Riau, K., Manajemen, P. S., \& Putera, U. (2019). Pengabdian Kepada Masyarakat : Pembekalan Memasuki Dunia Kerja Atau. 01(02), 2-9.

Kudhori, A., \& Setia, L. D. (2019). Implementasi Software Accounting Dalam Mewujudkan Pertanggungjawaban Keuangan Dan Akuntabilitas Publik Bagi LazisMu Kabupaten Madiun. DAYA-MAS, 4(September), 61-66.

Prima, A. P., \& Yusran, R. I. O. R. (2018). Pelatihan Financial Report Perusahaan Dagang Menggunakan Software MYOB Accounting pada SMK Hang Nadim Batam. Jurnal Manajemen Pendidikan Dan Pelatihan, 2(3), 1-4.

Rachmawati, R. (2016). Sistem Informasi Dilihat dari Aspek Kualitas Informasi Akuntansi. Jurnal Riset Akuntansi Dan Keuangan, 4(2), 985-992.

Ramadhani, R., \& Sribina, N. (2019). Pemanfaatan Media Pembelajaran SPSS untuk Meningkatkan Kemampuan Statistik Siswa SMK. SOLMA, 08(01), 159-170. http://dx.doi.org/10.29405/solma.v8i1.2996

Rohmah, M., Dewi, T. R., \& Amaliah, K. (2019). Upaya Peningkatan Kemampuan Siswa dalam Menggunakan Aplikasi Myob Accounting di SMK Negeri 1 Belitang Madang Raya. Jurnal Indonesia Mengabdi, 1(2), 57-59.

Siregar, I. F. (2018). Pelatihan Penggunaan Aplikasi Komputer Akuntansi Sebagai Media Untuk Meningkatkan Kompetensi Dan Pembelajaran Bagi Guru Dan Siswa Smk N 1 Tapung Pekanbaru. Jurnal Manajemen Pendidikan Dan Pelatihan, 2(3), 227-232.

Yuliana, H. (2013). Peranan Program Accurate Accounting Terhadap Efektivitas Pencatatan Laporan Penjualan Kredit. Jurnal Ilmiah Akuntansi Kesatuan, 1(3), 233-242. 